\title{
Locomotor activity of adult Dermacentor reticulatus ticks (Ixodida: Ixodidae) in natural conditions
}

\author{
Alicja Buczek', Zbigniew Zając', Aneta Woźniak', Dorota Kulina², Katarzyna Bartosik \\ ${ }^{1}$ Chair and Department of Biology and Parasitology, Medical University, Lublin, Poland \\ 2 Department of Basic Nursing and Medical Teaching, Medical University, Lublin, Poland
}

Buczek A, Zając Z, Woźniak A, Kulina D, Bartosik K. Locomotor activity of adult Dermacentor reticulatus ticks (Ixodida: Ixodidae) in natural conditions. Ann Agric Environ Med. 2017; 24(2): 271-275. doi: 10.5604/12321966.1230736

\begin{abstract}
Introduction and objective. Expansion into new areas and the great epidemiological significance of the $D$. reticulatus tick in Europe prompts investigations of its ethology. Therefore, the locomotor activity of $D$. reticulatus adult stages in an optimal habitat during the spring and autumn activity periods was analysed.

Materials and method. Marked $D$. reticulatus adults were placed at the central point of each experimental plot. At regular time intervals, specimens attached to the cloth used in the flagging method were collected, and the distance covered by the ticks was measured. In each collection round, the temperature and humidity level in the habitat was also measured. Results. Within 7 weeks, adult $D$. reticulatus ticks can cover an average distance of $60.71 \pm 44 \mathrm{~cm}$. The locomotor activity of adult stages is greater during the spring than the autumn activity period. Questing, females cover a greater distance $(66.35 \pm 100 \mathrm{~cm})$ than male ticks $(54.85 \pm 45 \mathrm{~cm})$. Adult stages are characterised by greater aggressiveness 24 hours after being released, i.e. $30 \%$ of females and $19 \%$ of males attempt to attach to host skin. The locomotor activity in adult ticks depends on the humidity of the habitat $(Z=-1.198 ; p=0.050)$. The temperature does not affect tick walking.

Conclusions. Given the low rates of horizontal locomotion of adult $D$. reticulatus ticks, the prevalence of the species in nature is determined by the presence of their hosts and humidity conditions ensuring their further development and survival. The dependence of $D$. reticulatus locomotor activity and aggressiveness on the humidity level implies an increased risk of host attacks in locations and periods that offer favourable humidity conditions for this species.
\end{abstract}

\section{- Key words}

Dermacentor reticulatus, locomotor activity, host-seeking activity, tick aggressiveness

\section{INTRODUCTION}

In recent years, $D$. reticulatus ticks have been noted in new localities in Europe [1], including areas that are strongly affected by anthropogenic factors [2,3]. The extension of the distribution range and increased abundance of $D$. reticulatus, probably caused by changes in the climate [4], weather [5, 6], and habitat conditions [7-9], increase the risk of host infestations by these ticks, and the incidence of tick-borne diseases. Therefore, investigation of the ethology of adult D. reticulatus stages in natural conditions is fundamental for determination of the risk posed to host species in tick habitats, and the prevalence of tick-borne diseases.

\section{OBJECTIVE}

The aim of this study was to investigate the locomotor activity of adult $D$. reticulatus ticks in their habitat during the spring and autumn peak activity periods from the aspect of health threats posed by this tick species to their hosts.

\footnotetext{
Address for correspondence: Alicja Buczek, Chair and Department of Biology and Parasitology, Medical University, Lublin, Poland

E-mail: alicja.buczek@umlub.pl

Received: 17 October 2016; accepted: 16 January 2017; first published on February 2017
}

\section{MATERIALS AND METHOD}

Study area and locality. The investigations were carried out in 2013-2014 in the Polesie National Park in centraleastern Poland during the spring and autumn activity peak in this part of the $D$. reticulatus geographical range [10]. The study locality was in a meadow overgrown by grass species representing the Poa pratensis-Festuca rubra community, with the dominance of Poa pratensis, P. trivialis, Festuca rubra, F. pratensis, and Alopecurus pratensis, as well as heather patches and low shrubs, mainly Betula spp. Earlier studies by the authors showed that this type of habitat offers the most favourable living conditions to the investigated tick species [11].

In the meadow, 8 circular, 2,826- $\mathrm{m}^{2}$ experimental plots were established, i.e. 4 for each of the spring and autumn activity peak periods in 2013 (C, D, and G, H) and in 2014 $(\mathrm{K}, \mathrm{L}$, and $\mathrm{O}, \mathrm{P})$. The plots were located at a distance of $\mathrm{ca}$. $30 \mathrm{~m}$ from each other and did not overlap.

Course of the experiments. Hungry D. reticulatus adults were collected by the flagging method in the area of the Park. In both years, ticks were collected twice, i.e. during the spring and autumn $D$. reticulatus activity peaks. The specimens were transferred to the laboratory in transport chambers, and males and females were separated in accordance with the identification key developed by Siuda [12]. Eight groups of ticks, each comprising 50 females and 50 males, were made, and the ticks marked with a marker on the dorsal side. 


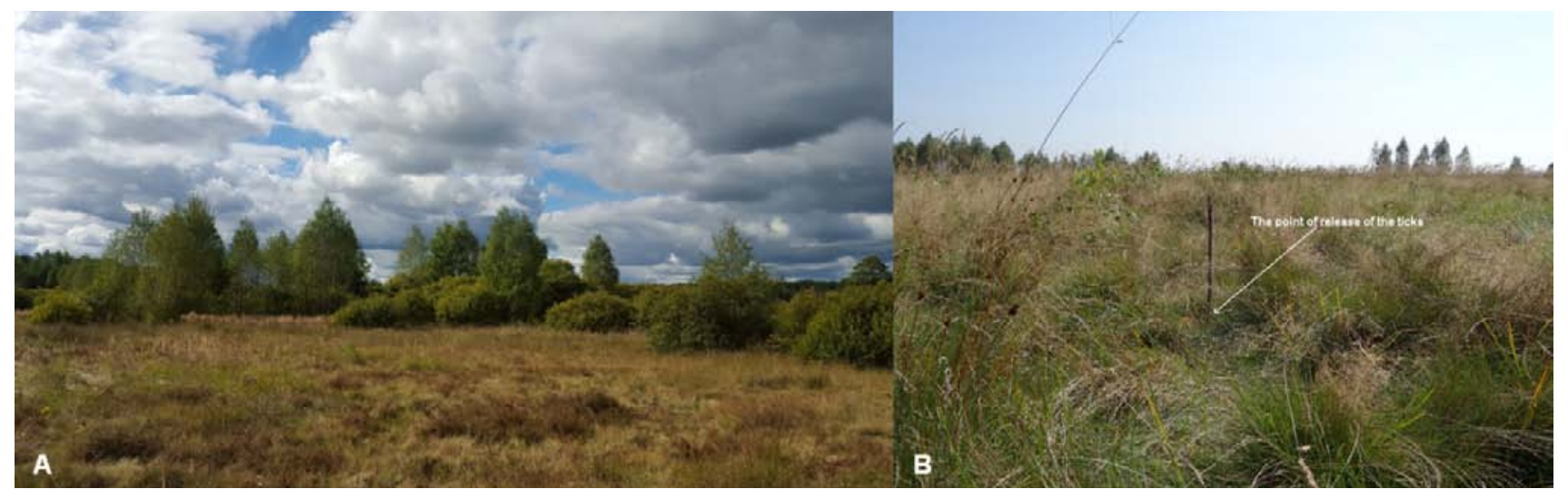

Figure 1. A- Dermacentor reticulatus habitat studied. B-central part of the experimental plot on which ticks were released

Ticks in each group were marked with a different colour. In total, 800 hungry D. reticulatus adults -400 females and 400 males - were marked.

The marked ticks were released in the centre of each plot (Fig. 1A, B). At regular time intervals, a ca. $1-\mathrm{m}^{2}$ flannel cloth was swept over the vegetation with a circular movement from the point of release of the ticks. The cloth was checked 2-3 times per one circle and, after measuring the distance covered by the ticks, attached specimens were collected and transported to the laboratory where they were preserved in a $70 \%$ ethanol solution.

Each time during the observations in the experimental plots, air temperature and humidity was measured at 3 heights, i.e. at ground level $(0 \mathrm{~cm})$, at the average height of plants growing in the habitat (30 $\mathrm{cm}$ above ground), and at the height of the shrubs present in the study area $(70 \mathrm{~cm})$. The measurements were averaged during the analysis of the experimental results.

In each plot, the investigations were conducted every day for the first 7 days following the release of the ticks, and next at 10-14-day intervals for 5 weeks in spring and 7 weeks in autumn at the highest diurnal activity peak of the species, i.e. at 13.00 and 14.00 [13]. The ticks were collected only on sunny, rainless days. No collection was carried out on days after heavy rains when the grass was wet.

Statistical analysis. Based on the data obtained, the arithmetic mean was calculated of the distance covered by adult ticks (females and males) in each experimental plot, and the collective distance in all localities in 2013 and 2014. The calculations were carried out using the Excel and Word programmes from the MS Office 2013 package.

The differences between the two groups were tested by the Mann-Whitney U test. A greater number of groups were compared with the Kruskal-Wallis chi-square test. A level of significance $\mathrm{p}=0.05$ was assumed.

Correlation between the tick locomotor activity and humidity, as well as temperature, was assessed using Spearman's rho-test.

\section{RESULTS}

As shown in the authors' investigations, D. reticulatus ticks present in the analysed habitat were able to move an average distance of $60.71 \pm 44.0 \mathrm{~cm}$ during 7 weeks, in an average temperature of $18.3^{\circ} \mathrm{C}$ and $56.7 \%$ humidity (Fig. 2). The

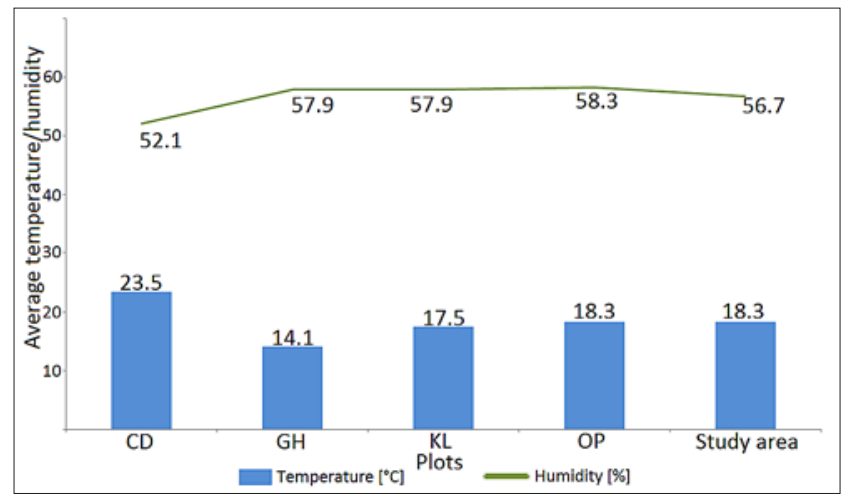

Figure 2. Average temperature and humidity in the experimental plots during the spring (CD-2013, KL-2014) and autumn (GH-2013, OP- 2014) activity peak of adult Dermacentor reticulatus ticks

females covered greater distances (mean $66.35 \pm 100.0 \mathrm{~cm}$ ) than males (mean $54.85 \pm 45.0 \mathrm{~cm}$ ). Additionally, single adult specimens were found at a distance of $23 \mathrm{~m}$ from the release site after 21 days.

The locomotor activity of $D$. reticulatus adults differed statistically significantly between the spring and autumn of $2013(\mathrm{Z}=-3.388 ; \mathrm{p}=0.001)$ and between the spring periods in 2013 and in $2014(Z=-5.355 ; p<0.001)$. In 2013, ticks covered greater distances in both the spring and the autumn activity periods than in 2014 (Tab. 1).

The locomotor activity of $D$. reticulatus adults differed in both periods of seasonal activity and in both study years (Fig. 2). In 2013, the locomotor activity of females was approximately two-fold higher in spring than in autumn. In 2014, higher female activity was noted in autumn. Similar trends were noted for males.

In spring 2014, the average distance covered by ticks was three-fold shorter (mean $35.60 \mathrm{~cm}$ ) than that in the analogous period of 2013 (mean $109.61 \mathrm{~cm}$ ). A statistical test confirmed the statistically significant differences in tick walking between spring 2013 and spring 2014 in experimental plots $C$ and $K$ $(\mathrm{Z}=-4.2851 ; \mathrm{p}<0.001), \mathrm{C}$ and $\mathrm{L}(\mathrm{Z}=-3.495 ; \mathrm{p}<0.001)$, and $\mathrm{D}$ and $\mathrm{K}(\mathrm{Z}=-4.549 ; \mathrm{p}<0.001)$.

In contrast, there were no statistically significant differences in the mean distances covered by adult $D$. reticulatus ticks which, on average, covered a radius of $54.82 \mathrm{~cm}$ and $42.80 \mathrm{~cm}$ $(\mathrm{Z}=-0.828 ; \mathrm{p}=0.408)$ during the autumn periods in both years. In the autumn of both years, differences in the locomotor activity between females and males were noted (Tab. 2). $1.68 \%-4.60 \%$ of adult specimens (including $2.82 \%-4.88 \%$ 
Table 1. Average distance $(\mathrm{cm})$ covered by adult $D$. reticulatus ticks during 5 weeks (spring) and 7 weeks (autumn) in experimental plots

\begin{tabular}{|c|c|c|c|c|c|c|c|}
\hline & Season & Plots & $\mathrm{N}$ & $M$ & SD & Min & Max \\
\hline \multirow{5}{*}{ Females } & spring 2013 & $C D$ & 77.00 & 139.87 & 287.35 & 0.00 & 600.00 \\
\hline & spring 2014 & $\mathrm{KL}$ & 54.00 & 29.11 & 42.09 & 0.00 & 210.00 \\
\hline & autumn 2013 & $\mathrm{GH}$ & 56.00 & 61.25 & 62.84 & 0.00 & 240.00 \\
\hline & autumn 2014 & OP & 50.00 & 35.20 & 41.47 & 0.00 & 150.00 \\
\hline & average & & 237.00 & 66.35 & 100.04 & 0.00 & 600.00 \\
\hline \multirow{5}{*}{ Males } & spring 2013 & $C D$ & 77.00 & 79.35 & 152.68 & 0.00 & 960.00 \\
\hline & spring 2014 & $\mathrm{KL}$ & 54.00 & 41.25 & 34.22 & 0.00 & 150.00 \\
\hline & autumn 2013 & $\mathrm{GH}$ & 56.00 & 48.39 & 86.38 & 0.00 & 450.00 \\
\hline & autumn2014 & OP & 50.00 & 50.40 & 42.52 & 0.00 & 170.00 \\
\hline & average & & 237.00 & 54.85 & 45.01 & 0.00 & 960.00 \\
\hline \multirow{5}{*}{ Total } & spring 2013 & $C D$ & 77.00 & 109.61 & 120.33 & 0.00 & 600.00 \\
\hline & spring 2014 & $\mathrm{KL}$ & 54.00 & 35.60 & 40.00 & 0.00 & 280.00 \\
\hline & autumn 2013 & $\mathrm{GH}$ & 56.00 & 54.82 & 58.11 & 0.00 & 450.00 \\
\hline & autumn 2014 & OP & 50.00 & 42.80 & 50.00 & 0.00 & 240.00 \\
\hline & average & & 237.00 & 60.71 & 44.00 & 0.00 & 600.00 \\
\hline
\end{tabular}

$\mathrm{N}$ - number of samples; $\mathrm{M}$ - mean; SD - standard deviation

of females and $0-4.35 \%$ of males), and $4.26 \%-7.89 \%$ of specimens (including $1.96 \%-8.57 \%$ of females and $1.96 \%-$ $6.98 \%$ of males) remained at the release site during the spring and autumn periods, respectively (Tab. 2).

The highest locomotor activity in the spring and autumn seasonal activity periods was noted after 24 hours of the experiments (Tab. 3). The high locomotor activity of adult D. reticulatus ticks persisted for 120 hours in spring and 96 hours in autumn (Tab. 3).

The greatest horizontal walking ability was exhibited by adult stages in a humidity range of $55 \%-65 \%$. Statistical analysis showed a significant effect of humidity $(Z=-1.198$; $\mathrm{p}=0.050)$ on the locomotor activity of adult $D$. reticulatus stages. In turn, no correlation was found between the temperature and locomotor activity of the ticks in the analysed experimental plots (Spearman's rho-test, from Z=$0.258 ; \mathrm{p}=0.084$ to $\mathrm{Z}=-0.019 ; \mathrm{p}=0.921$ ).
Table 3. Host-seeking activity of adult $D$. reticulatus ticks in experimental plots during seasonal activity peaks

\begin{tabular}{|c|c|c|c|c|c|c|}
\hline \multirow[b]{2}{*}{$\begin{array}{l}\text { Plots } \\
\text { (season) }\end{array}$} & \multirow[b]{2}{*}{$\begin{array}{c}\text { Average } \\
\text { temperature } \\
{\left[{ }^{\circ} \mathrm{C}\right]}\end{array}$} & \multirow[b]{2}{*}{$\begin{array}{c}\text { Average } \\
\text { humidity } \\
{[\%]}\end{array}$} & \multirow[b]{2}{*}{$\begin{array}{c}\text { Time } \\
{[\mathrm{h}]}\end{array}$} & \multicolumn{3}{|c|}{ Active ticks } \\
\hline & & & & $\begin{array}{c}\text { Females } \\
(\mathrm{N}=50) \\
{[\%]}\end{array}$ & $\begin{array}{c}\text { Males } \\
(\mathrm{N}=50) \\
{[\%]}\end{array}$ & $\begin{array}{c}\text { Total } \\
{[\%]}\end{array}$ \\
\hline \multirow{7}{*}{$\begin{array}{l}C D \text { (spring } \\
2013 \text { ) }\end{array}$} & \multirow{7}{*}{23.5} & \multirow{7}{*}{52.1} & 24 & 30.00 & 19.00 & 24.50 \\
\hline & & & 72 & 16.00 & 15.00 & 15.50 \\
\hline & & & 96 & 9.00 & 6.00 & 7.50 \\
\hline & & & 120 & 11.00 & 7.00 & 9.00 \\
\hline & & & 144 & 5.00 & 1.00 & 3.00 \\
\hline & & & 336 & 1.00 & 2.00 & 1.50 \\
\hline & & & Total & 72.00 & 50.00 & 61.00 \\
\hline \multirow{6}{*}{$\begin{array}{l}\mathrm{GH} \\
\text { (autumn } \\
\text { 2013) }\end{array}$} & \multirow{6}{*}{14.1} & \multirow{6}{*}{57.9} & 24 & 21.00 & 17.00 & 19.00 \\
\hline & & & 72 & 10.00 & 10.00 & 10.00 \\
\hline & & & 96 & 8.00 & 1.00 & 4.50 \\
\hline & & & 144 & 3.00 & 4.00 & 3.50 \\
\hline & & & 552 & 3.00 & 3.00 & 3.00 \\
\hline & & & Total & 45.00 & 35.00 & 40.00 \\
\hline \multirow{7}{*}{$\begin{array}{l}\text { KL (spring } \\
2014 \text { ) }\end{array}$} & \multirow{7}{*}{17.5} & \multirow{7}{*}{57.9} & 24 & 16.00 & 15.00 & 15.5 \\
\hline & & & 48 & 4.00 & 7.00 & 5.50 \\
\hline & & & 72 & 8.00 & 9.00 & 8.50 \\
\hline & & & 96 & 6.00 & 6.00 & 6.00 \\
\hline & & & 120 & 5.00 & 4.00 & 4.50 \\
\hline & & & 552 & 2.00 & 3.00 & 2.50 \\
\hline & & & Total & 41.00 & 44.00 & 42.5 \\
\hline \multirow{6}{*}{$\begin{array}{l}\text { OP } \\
\text { (autumn } \\
2014 \text { ) }\end{array}$} & \multirow{6}{*}{18.3} & \multirow{6}{*}{58.3} & 24 & 12.00 & 18.00 & 15.00 \\
\hline & & & 96 & 9.00 & 11.00 & 10.00 \\
\hline & & & 120 & 5.00 & 8.00 & 6.50 \\
\hline & & & 144 & 3.00 & 1.00 & 2.00 \\
\hline & & & 168 & 1.00 & 5.00 & 3.00 \\
\hline & & & Total & 30.00 & 43.00 & 36.00 \\
\hline
\end{tabular}

$\mathrm{N}$ - number of samples

Table 2. Locomotor activity of adult $D$. reticulatus ticks in experimental plots

\begin{tabular}{|c|c|c|c|c|c|c|c|c|c|c|c|c|}
\hline \multirow{2}{*}{$\begin{array}{l}\text { Plots } \\
\text { Distance } \\
{[\mathrm{cm}]}\end{array}$} & \multicolumn{3}{|c|}{$C D$} & \multicolumn{3}{|c|}{$\mathrm{GH}$} & \multicolumn{3}{|c|}{$\mathrm{KL}$} & \multicolumn{3}{|c|}{ OP } \\
\hline & $\begin{array}{c}\text { Females } \\
(\mathrm{N}=50)[\%]\end{array}$ & $\begin{array}{c}\text { Males } \\
(\mathrm{N}=50)[\%]\end{array}$ & Total [\%] & $\begin{array}{c}\text { Females } \\
(\mathrm{N}=50)[\%]\end{array}$ & $\begin{array}{c}\text { Males } \\
(\mathrm{N}=50)[\%]\end{array}$ & Total [\%] & $\begin{array}{l}\text { Females } \\
{[\%](\mathrm{N}=50)}\end{array}$ & $\begin{array}{c}\text { Males [\%] } \\
(\mathrm{N}=50)\end{array}$ & $\begin{array}{l}\text { Total[\%] } \\
(\mathrm{N}=100)\end{array}$ & $\begin{array}{c}\text { Females } \\
(\mathrm{N}=50)[\%]\end{array}$ & $\begin{array}{c}\text { Males } \\
(\mathrm{N}=50)[\%]\end{array}$ & $\begin{array}{c}\text { Total } \\
{[\%]}\end{array}$ \\
\hline 0 & 2.82 & 0.00 & 1.68 & 1.96 & 6.98 & 4.26 & 4.88 & 4.35 & 4.60 & 8.57 & 7.84 & 8.14 \\
\hline 10 & 8.45 & 8.33 & 8.40 & 7.84 & 20.93 & 13.83 & 12.20 & 6.52 & 9.20 & 0.00 & 1.96 & 1.16 \\
\hline 20 & 9.86 & 10.42 & 10.08 & 5.88 & 13.95 & 9.57 & 14.63 & 6.52 & 10.34 & 8.57 & 13.73 & 11.63 \\
\hline 30 & 11.27 & 8.33 & 10.08 & 5.88 & 13.95 & 9.57 & 19.51 & 15.22 & 17.24 & 8.57 & 9.80 & 9.30 \\
\hline 40 & 9.86 & 6.25 & 8.40 & 15.69 & 11.63 & 13.83 & 21.95 & 17.39 & 19.54 & 22.86 & 21.57 & 22.09 \\
\hline 50 & 5.63 & 6.25 & 5.88 & 7.84 & 0.00 & 4.26 & 4.88 & 10.87 & 8.05 & 11.43 & 7.84 & 9.30 \\
\hline 60 & 11.27 & 8.33 & 10.08 & 9.80 & 9.30 & 9.57 & 7.32 & 17.39 & 12.64 & 17.14 & 11.76 & 13.95 \\
\hline 70 & 2.82 & 4.17 & 3.36 & 3.92 & 0.00 & 2.13 & 7.32 & 10.87 & 9.20 & 8.57 & 9.80 & 9.30 \\
\hline 90 & 1.41 & 4.17 & 2.52 & 3.92 & 0.00 & 2.13 & 0.00 & 4.35 & 2.30 & 0.00 & 1.96 & 1.16 \\
\hline 100 & 4.23 & 0.00 & 2.52 & 3.92 & 6.98 & 5.32 & 2.44 & 0.00 & 1.15 & 2.86 & 3.92 & 3.49 \\
\hline
\end{tabular}

CD - spring 2013; GH - autumn 2013; KL - spring 2014; OP - autumn 2014 


\section{DISCUSSION}

Tick locomotor activity is an important element of the life strategy developed by these arthropods in order to quest for hosts and survive in natural conditions. The presented study shows that in field conditions hungry $D$. reticulatus adults cover a short distance (on average ca. $60 \mathrm{~cm}$ ) before attempting to attack a host during the spring and autumn activity peaks. The distance covered by ticks, however, may be substantially longer, as the route is not a straight line and, like other tick species [14-17], they move both horizontally and vertically.

The presence of hungry specimens after 3 weeks at a distance of $23 \mathrm{~m}$ from the site of release, thereof may indicate involvement of animal species or humans who are not specific hosts of these ticks in the transfer of this species to new habitats. A significant role may also be played by host animals, which may drop unattached tick specimens from their skin while self-cleaning.

The locomotor activity of adult $D$. reticulatus ticks is lower than that of other non-nidicolous ticks with an ambushing life strategy, e.g. representatives of the genus Ixodes. In field conditions, Ixodes scapularis nymphs moved an average distance of 2-3 m within 2-3 weeks. Adult stages covered a greater distance. Some specimens were collected at a distance from 5-6 m from the site of tick release after 3-4 weeks [18]. The limited walking capability of adult $D$. reticulatus ticks in natural conditions probably, determines the mosaic distribution of these ticks, and their presence in habitats ensuring appropriate humidity and food supply through host availability. The poor mobility of adult $D$. reticulatus stages is compensated for by their considerable aggressiveness facilitating questing. The majority of analysed ticks attempted to attach to the cloth already after 24 hours in a new locality.

The differences in the behaviour of the $D$. reticulatus ticks noted in this study may be determined by the different physiological age or status of the ticks, e.g. the degree of body hydration.

The distance covered by ticks may also depend on habitat and climate conditions prevailing in the area of their occurrence. In both study years, differences in the weather were noted in the Polesie National Park (Tab. 4). In 2014, the conditions in the $D$. reticulatus habitat changed due to land management work (cutting down shrubs and trees, mainly birch specimens) aimed at exposing heath land. These treatments contributed to all-day insolation of an area that had previously been partially shaded; this may have changed the habitat conditions and determined tick behaviour. In unfavourable conditions, ticks stayed in the lower layers of vegetation, thereby having protection against water loss [19].

The correlation between the locomotor activity of adult D. reticulatus ticks and humidity implies a higher risk of host attack in the humid conditions preferred by this species. The greatest locomotor activity is was exhibited by adult D. reticulatus stages in various habitats of central-eastern Poland at a humidity of $55-65 \%$.

Tick host-seeking behaviour is also influenced by other factors that were not analysed in the presented study, including some host-produced substances [14, 20-24].

In spring and autumn, the host-seeking activity of adult D. reticulatus ticks differs. In spring, the ticks cover greater distances than in autumn, which is associated with the
Table 4. Weather conditions in the area of Polesie National Park (20122014) (www.tutiempo.net)

\begin{tabular}{cccccccc}
\hline $\begin{array}{c}\text { Average } \\
\text { temp. } \\
{\left[{ }^{\circ} \mathrm{C}\right]}\end{array}$ & $\begin{array}{c}\text { Average } \\
\text { max. } \\
\text { temp. } \\
{\left[{ }^{\circ} \mathrm{C}\right]}\end{array}$ & $\begin{array}{c}\text { Average } \\
\text { min. } \\
\text { temp. } \\
{\left[{ }^{\circ} \mathrm{C}\right]}\end{array}$ & $\begin{array}{c}\text { Total } \\
\text { precipi- } \\
\text { tation } \\
{[\mathrm{mm}]}\end{array}$ & $\begin{array}{c}\text { No. of } \\
\text { rainy } \\
\text { days }\end{array}$ & $\begin{array}{c}\text { No. of } \\
\text { days with } \\
\text { snow } \\
\text { cover }\end{array}$ & $\begin{array}{c}\text { No. of } \\
\text { days with } \\
\text { fog }\end{array}$ \\
\hline 2012 & 8.2 & 12.8 & 3.5 & 499.56 & 183 & 74 & 45 \\
\hline 2013 & 8.4 & 12.6 & 4.1 & 674.62 & 163 & 72 & 56 \\
\hline 2014 & 9.0 & 13.7 & 4.6 & 738.42 & 181 & 37 & 61 \\
\hline
\end{tabular}

physiology of these mites. The greater locomotor activity of adult $D$. reticulatus ticks in the quest for hosts noted in this study during the spring months, compared with that in the autumn months, increased the chance of finding a host, and producing the next generation in favourable environmental conditions. Host blood ingestion is obligatory for the normal development of female and male germ cells, insemination, and oviposition. The weaker locomotor activity of adult stages noted in the autumn period might also have resulted from the fact that the group of specimens examined may have physiologically comprised young adults moulted from nymphs shortly before being collected in the habitat in this field study.

As indicated by the field observations, tick females are characterised by greater locomotor activity than males, which follow the source of pheromones secreted by hostinfesting females [25]. In Metastriata ticks, represented by D. reticulatus, mating takes place on the host.

The presented study demonstrating the relationship between the locomotor activity of $D$. reticulatus and the level of humidity in the habitat are in agreement with the results reported by Crooks and Randolph [24], who observed movement of I. ricinus ticks towards water-saturated air in the case of even minimal water loss. Loss of water through the evaporation process may lead to lowered tick activity and reduce the chance of finding a host.

\section{CONCLUSIONS}

The study shows that $D$. reticulatus adults move within a small area, but are an aggressive species. Therefore, it seems that a population of these ticks can only survive in habitats ensuring the presence of hosts and suitable moisture conditions. The greater locomotor activity in the favourable humidity range of 55\%-65\% indicates increased threats to host health posed by tick attacks.

\section{Acknowledgments}

The authors wish to thank Dr Jarosław Szymański and Dr Szymon Kolasa from the Directorate of the Polesie National Park for the assistance in conducting the study.

\section{REFERENCES}

1. Földvári G, Široký P, Szekeres S, Majoros G, Sprong H. Dermacentor reticulatus: a vector on the rise. Parasit Vectors. 2016; 9(1): 314.

2. Vatansever Z, Gargili A, Aysul NS, Sengoz G, Estrada-Peña A. Ticks biting humans in the urban area of Istanbul. Parasitol Res. 2008; 102(3): 551-553.

3. Buczek A, Bartosik K. Ticks (Ixodida: Ixodidae, Amblyommidae) in south-eastern Poland and their medical and epidemiological importance. Zdr Publ. 2011; 121(4): 392-397. 
4. Gray JS, Dautel H, Estrada-Peňa A, Kahl O, Lindgren E. Effects of climate change on ticks and tick-borne diseases in Europe. Interdiscip Perspectives Infect Dis. 2009; 593232: 1-12.

5. Buczek A, Bartosik K, Wiśniowski L, Tomasiewicz K. Changes in population abundance of adult Dermacentor reticulatus (Acari: Amblyommidae) in long-term investigations in eastern Poland. Ann Agric Environ Med. 2013; 20(2): 269-272.

6. Buczek A, Bartosik K, Zając Z. Changes in the activity of adult stages of Dermacentor reticulatus (Ixodida: Amblyommidae) induced by weather factors in eastern Poland. Parasit Vectors. 2014; 7: 245.

7. Sréter T, Széll Z, Varga I. Spatial distribution of Dermacentor reticulatus and Ixodes ricinus in Hungary: evidence for change? Vet Parasitol. 2005; 128(3-4): 347-351.

8. Bullová E, Lukáň M, Stanko M, Petko B. Spatial distribution of Dermacentor reticulatus tick in Slovakia in the beginning of the 21st century. Vet Parasitol. 2009; 165(3-4): 357-360.

9. Široký P, Kubelová M, Bednář M, Modrý D, Hubálek Z, Tkadlec E. The distribution and spreading pattern of Dermacentor reticulatus over its threshold area in the Czech Republic-How much is range of this vector expanding? Vet Parasitol. 2011; 183(1-2): 130-135.

10. Bartosik K, Wiśniowski L, Buczek A. Abundance and seasonal activity of adult Dermacentor reticulatus (Acari: Amblyommidae) in eastern Poland in relation to meteorological conditions and the photoperiod. Ann Agric Environ Med. 2011; 18(2): 340-344.

11. Zając Z, Bartosik K, Buczek A. Factors influencing the distribution and activity of Dermacentor reticulatus (F.) ticks in an anthropopressureunaffected area in central-eastern Poland. Ann Agric Environ Med. 2016; 23(2): 270-275.

12. Siuda K. Ticks (Acari: Ixodida) of Poland. Part II Taxonomy and Distribution. Warszawa PTP, 1993 (in Polish).

13. Bartosik K, Wiśniowski L, Buczek A. Questing behavior of Dermacentor reticulatus adults (Acari: Amblyommidae) during diurnal activity periods in eastern Poland. J Med Entomol. 2012; 49(4): 859-864.

14. McMahon C, Guerin P. Attraction of the tropical bont tick, Amblyomma variegatum, to human breath and to the breath components acetone, $\mathrm{NO}$ and $\mathrm{CO}_{2}$. Naturwissenschaften 2002; 89(7): 311-315.
15. Perret JL, Guerin PM, Diehl PA, Vlimant M, Gern L. Darkness favours mobility and saturation deficit limits questing duration in Ixodes ricinus, the tick vector of Lyme disease in Europe. J Exp Biol. 2003; 206(11): 1809-1815.

16. Lane RS, Mun J, Peribáňez MA, Stubbs HA. Host-seeking behaviour of Ixodes pacificus (Acari: Ixodidae) nymphs in relation to environmental parameters in dense-woodland and woodland-grass habitats. J Vector Ecol. 2007; 32(2): 342-357.

17. Lane RS, Mun J, Peribáňez MA, Stubbs HA. Horizontal and vertical movements of host-seeking Ixodes pacificus (Acari: Ixodidae) nymphs in a hardwood forest. J Vector Ecol. 2009; 34(2): 252-266.

18. Carroll JF, Schmidtmann ET. Dispersal of blacklegged tick (Acari: Ixodidae) nymphs and adults at the woods-pasture interface. J Med Entomol. 1996; 33(4): 554-558.

19. Knulle W, Rudolph D. Humidity relationships and water balance of ticks. In: Obenchain FD, Galun R, (eds). Physiology of Ticks, Oxford; 1982. p. 43-70.

20. Norval RAI, Peter T, Yunker CE, Sonenshine DE, Burridge MJ. Responses of the ticks Amblyomma hebraeum and A. variegatum to known or potential components of the aggregation-attachment pheromone. I. Long-range attraction. Exp Appl Acarol. 1991; 13(1): $11-18$.

21. Carroll JF, Mills GD, Schmidtman ET. Field and laboratory responses of adult Ixodes scapularis (Acari: Ixodidae) to kairomones produced by white-tailed deer. J Med Entomol. 1996; 33(4): 640-644.

22. Grenacher S, Kröber T, Guerin PM, Vlimant M. Behavioural and chemoreceptor cell responses of the tick, Ixodes ricinus, to its own faeces and faecal constituens. Exp Appl Acarol. 2001; 25(8): 641-660.

23. Carroll JF. How specific are host-produced kairomones to host-seeking ixodid ticks? Exp Appl Acarol. 2002; 28(1-4): 155-161.

24. Crooks E, Randolph SE. Walking by Ixodes ricinus ticks: intrinsic and extrinsic factors determine the attraction of moisture or host odour. J Med Exp Biol. 2006; 209(11): 2138-2142.

25. Sonenshine DE. Biology of Ticks, vol. 1. Oxford University Press, 1991. 